\title{
Mixotrophy in marine picocyanobacteria: use of organic compounds by Prochlorococcus and Synechococcus
}

\author{
M. C. Muñoz-Marín (iD ${ }^{1} \cdot$ G. Gómez-Baena $^{1} \cdot$ A. López-Lozano ${ }^{1} \cdot$ J. A. Moreno-Cabezuelo ${ }^{1} \cdot$ J. Díez $^{1}$ • \\ J. M. García-Fernández ${ }^{1}$
}

Received: 2 October 2019 / Revised: 28 January 2020 / Accepted: 28 January 2020 / Published online: 7 February 2020

(c) The Author(s), under exclusive licence to International Society for Microbial Ecology 2020

\begin{abstract}
Marine picocyanobacteria of the Prochlorococcus and Synechococcus genera have been longtime considered as autotrophic organisms. However, compelling evidence published over the last 15 years shows that these organisms can use different organic compounds containing key elements to survive in oligotrophic oceans, such as $\mathrm{N}$ (amino acids, amino sugars), $\mathrm{S}$ (dimethylsulfoniopropionate, DMSP), or P (ATP). Furthermore, marine picocyanobacteria can also take up glucose and use it as a source of carbon and energy, despite the fact that this compound is devoid of limiting elements and can also be synthesized by using standard metabolic pathways. This review will outline the main findings suggesting mixotrophy in the marine picocyanobacteria Prochlorococcus and Synechococcus, and its ecological relevance for these important primary producers.
\end{abstract}

\section{Introduction}

Cyanobacteria are the only known prokaryotes able to perform oxygenic photosynthesis, which allowed them to play a crucial role in the formation of atmospheric oxygen around 2.3 billion years ago [1]. The marine cyanobacteria Prochlorococcus [2] and Synechococcus [3] are the most abundant photosynthetic organisms on Earth and contribute about $25 \%$ of primary production in the oceans [4]. Therefore, they play a significant role in the global carbon cycle, having a substantial implication in the maintenance of the biosphere [5-9]. As a consequence, they are considered as model organisms in marine ecology, used in a

These authors contributed equally: M. C. Muñoz-Marín, G. Gómez-Baena

Supplementary information The online version of this article (https:// doi.org/10.1038/s41396-020-0603-9) contains supplementary material, which is available to authorized users.

\section{J. M. García-Fernández}

jmgarcia@uco.es

1 Departamento de Bioquímica y Biología Molecular, Campus de Excelencia Internacional Agroalimentario CeiA3, Edificio Severo Ochoa, planta 1, ala Este, Campus de Rabanales, Universidad de Córdoba, 14071 Córdoba, Spain large series of studies (over 2200 papers published since their discovery) and providing a huge amount of genomic and metagenomic datasets [10].

\section{Mixotrophy in cyanobacteria}

The term mixotrophy was first used by Pfeffer in 1897 referring plants with low-chlorophyll content that need to complement their nutritional needs by the uptake of organic substances [11]. It has traditionally been defined as alternative forms of carbon acquisition but can also comprise the acquisition of molecules containing nitrogen, phosphorus, trace elements (as $\mathrm{Fe}$ ), vitamins, and high-energy compounds such as ATP [12]. This term soon expanded to refer to the combination of different nutritional pathways in a single organism. The word photoheterotroph refers to a prokaryotic organism that uses light to enhance uptake of organic molecules [13, 14].

In cyanobacteria, mixotrophy was early described by Rippka [15]. In 1967, it was reported that four blue-green algae (cyanobacteria) could assimilate acetate in a light dependent reaction [16]. Years later, it was shown that half of the strains tested that far were capable of heterotrophic growth [17].

Marine cyanobacteria are oxygenic prokaryotes that use $\mathrm{CO}_{2}$ as a carbon source owing to the presence of a 
chlorophyll-based light harvesting complex and thus, these organisms have been traditionally considered photoautotrophs [18]. However, the concept of marine cyanobacteria being purely photoautotrophic is currently seriously questioned. Early genomic data from Prochlorococcus and Synechococcus strains, such as the presence of genes encoding amino acid, oligopeptide, and sugar transporters [19-21], suggested that at least certain strains are not pure photoautotrophs. This has a great ecological importance since mixotrophic bacteria could dominate broader aquatic environments due to their capability to use additional resources compared to both photoautotrophic and organoheterotrophic bacteria [22].

Cells have a limited surface area, and mixotrophs must partition it to accommodate transport sites for both inorganic and organic resources. The mixotrophy strategy requires an investment in both photosynthetic and heterotrophic cellular machinery, and the profit must outweigh these costs to be energetically advantageous. These costs may lower the efficient use of resources by the mixotroph, and it can result in a reduced growth rate when compared with specialist organisms [23]. However, the fact that mixotrophs successfully coexist with specialists under different conditions indicates that the benefits of mixotrophy in nature can compensate the anticipated high costs of preserving two nutritional systems [24].

Hypothetically, mixotrophs require duplication of energy investment since they need not only photosynthetic but uptake cellular machinery. However, laboratory experiments suggest that they may be more ecologically successful when light energy is plentiful but nutrient resources are limited [25], as it is the case of oligotrophic oceanic gyres. The strong pressure of natural selection to eliminate redundant or not essential genes [26] makes improbable for planktonic prokaryotes to maintain genes non vital for cell survival. Therefore, the conservation of genes for the active uptake of some organic molecules by marine cyanobacteria must be energetically beneficial [27].

\section{Amino acids}

Amino acids are a source of carbon and nitrogen for marine picocyanobacteria. Prochlorococcus and Synechococcus are responsible for a large fraction of the oceanic amino acid incorporation [28-35]. Amino acid uptake by marine picoplankton was early attributed to photosynthetic microorganisms, since chlorophyll $a$-containing picoplankton from different oceanic areas along with cultures of some representative marine Synechococcus strains (WH7803, WH8101), showed light-stimulated incorporation of amino acids [31]. The use of on board flow cytometry cell sorters allowed the identification of marine cyanobacteria as the group of microorganisms incorporating amino acids in both oligotrophic and mesotrophic areas of the oceans [33]. These results were in good agreement with the Prochlorococcus genome sequences, which showed the presence of genes encoding for amino acids transporters [21]. There is an important level of diversity in the presence of genes encoding transporters of organic compounds in different picocyanobacterial strains (Fig. 1, Supplementary Table 1). For instance, amino acid $\mathrm{ABC}$ transporters membrane protein of two different families (PAAT family (TC 3.A.1.3.-) and HAAT family (TC 3.A.1.4.-) are present in the genomes of marine and freshwater cyanobacteria, but the HAAT family is only present in the LL IV clade (Fig. 1, Supplementary Table 1).

The assumed nature of Prochlorococcus and Synechococcus as strict phototrophic organisms led to firstly consider amino acids as a nitrogen source, instead of an evidence of mixotrophy in marine cyanobacteria. The ecological significance of amino acid uptake seems to be different for the predominant cyanobacterial genera in the ocean: while Prochlorococcus is responsible for $33 \%$ of the bacterial methionine turnover in oligotrophic regions (where this organism represents around 95\% of all cyanobacteria), the methionine consumption in mesotrophic regions attributed to Synechococcus (which dominates those waters, accounting for $97 \%$ of all cyanobacteria), is of only $3 \%$ of bacterial methionine turnover [33]. Table 1 shows the uptake rates for different organic compounds, determined in Prochlorococcus and Synechococcus in the field or in laboratory experiments. Comparison with uptake rates of inorganic $\mathrm{N}$ compounds determined in the field [36] shows that the values compiled in Table 1 are in similar ranges of magnitude (amol/cell day). Interestingly, the uptake rates for specific compounds can be higher in Synechococcus (i.e., dimethylsulfoniopropionate (DMSP) [32]) or in Prochlorococcus (i.e., amino acids [33]).

Prochlorococcus and Synechococcus can be responsible for up to $10 \%$ of total amino acid uptake in some areas where they represent $10 \%$ of prokaryotes [30]. Hence, in oceanic regions with a high abundance of these picocyanobacteria, amino acid uptake is potentially large. Light-stimulated amino acid assimilation reported in those areas might be attributed to both genera of cyanobacteria, although light-stimulated amino acid uptake has been described for areas where their abundances are low [28, 30, 37-40]. The study of the mechanism of light enhancement of uptake systems in marine cyanobacteria will allow to clarify whether it is a specific effect or derived from growth.

\section{DMSP}

DMSP is a tertiary sulfonium compound that is a significant source of carbon and sulfur to the microbial community 


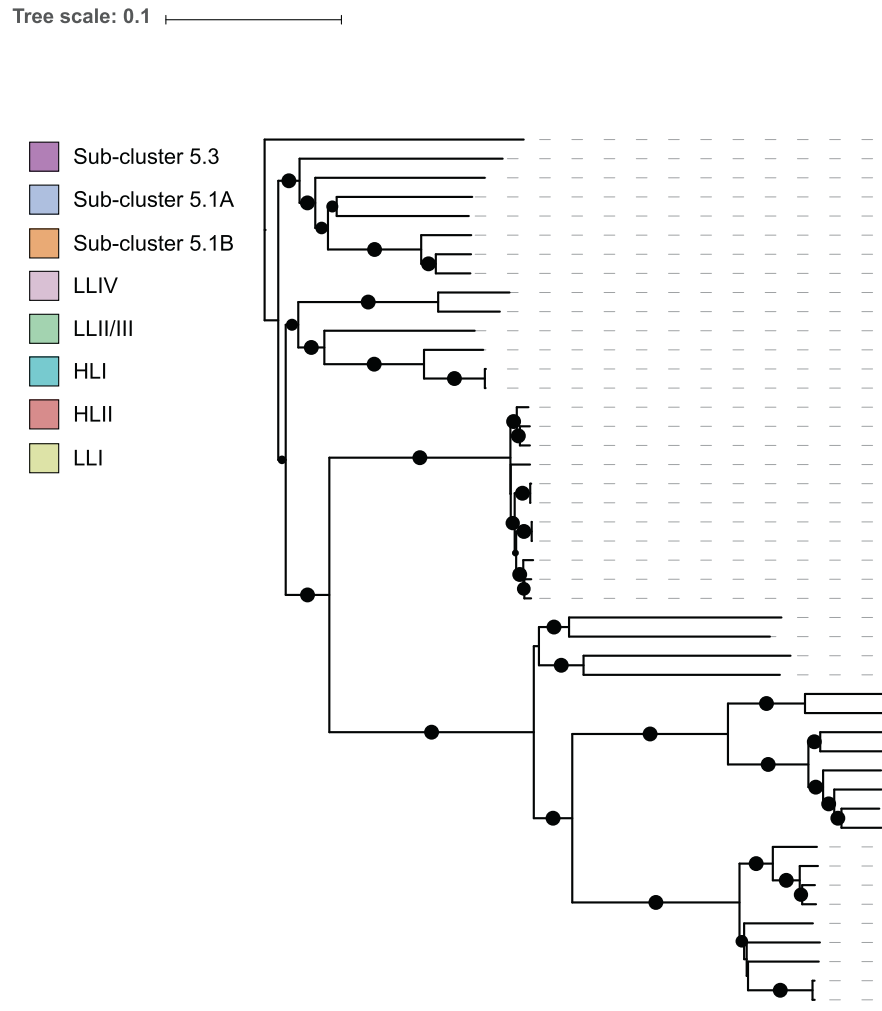

Fig. 1 Phylogenetic species tree representing the diverse capabilities of selected Prochlorococcus and Synechococcus strains to take up different organic compounds. Neighbor joining phylogenetic tree was based on the collection of Prochlorococcus and Synechococcus sequences of the genomes used by [10]. Bootstrap values (100 replicates) above $80 \%$ are indicated on the branches by sizescaled black dots at nodes. The sequences corresponding to Synechococcus $\mathrm{sp}$. RCC307 acted as outgroup in this tree. A, table showing the presence/absence of genes encoding sugars $(\mathrm{glcH}$ and $\mathrm{glcP})$, amino

[41, 42], acting as a link between primary production and chemoheterotrophic bacteria [43]. DMSP is produced by phytoplanktonic organisms, likely with osmoregulatory and antioxidant functions [42, 44].

DMSP synthesized by phytoplankton taxa can be used by the cyanobacteria Synechococcus and Prochlorococcus $[45,46]$, which were found to be major consumers of this organic-sulfur compound. Both genera are responsible for about $20 \%$ of DMSP assimilation by prokaryotes, a similar proportion to that of other abundant bacterial groups in the sea $[45,46]$. Light affects DMSP assimilation by marine Synechococcus, being the proportion of DMSP assimilated greater when incubated in the light than in the dark [45].

Although concentrations of sulfate are typically $10^{7}$-fold greater than those of DMSP in the ocean, marine Synechococcus strains show a high uptake of DMSP [45], indicating that Synechococcus would prefer DMSP over sulfate because it is energetically more efficient the incorporation of reduced sulfur from DMSP directly than the

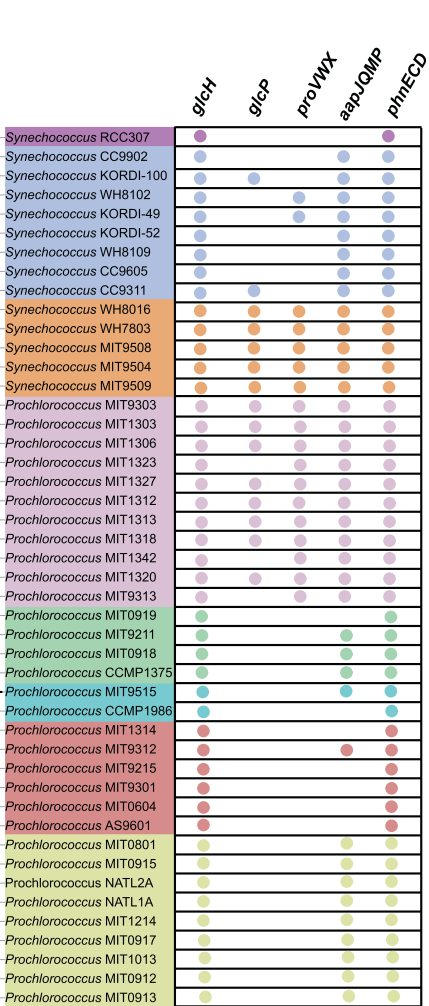

A

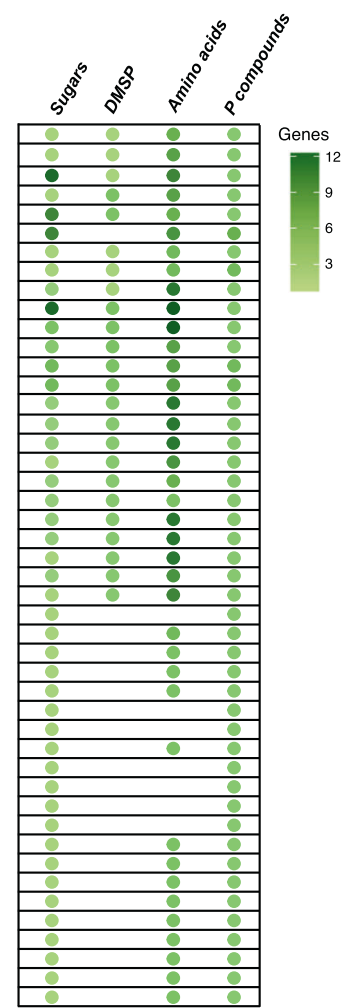

B acids (aapJQMP), DMSP (proVWX), and phosphonate transporters ( $p h n E C D)$. Filled circles represent the presence of the indicated genes. $\mathrm{B}$, table showing the number of genes involved in sugars $(\mathrm{glcH}, \mathrm{glcP}$, CUT1, malK), DMSP (proVWX), amino acids (aapJQMP), and $\mathrm{P}$ compounds uptake ( $p h n E C D$ ). The green circles represent the number of genes for each category in the corresponding strain, according to the scale shown on the side. Presence of genes is described in Supplementary Table 1 .

assimilation of the more oxidized sulfur from sulfate [41]. This preference of reduced compounds over the corresponding oxidized ones had previously been observed for nitrogen assimilation in picocyanobacteria, since Prochlorococcus strains prefer ammonium to nitrate and nitrite, to the extent that some of them are not able to metabolize nitrate and lack the gene encoding nitrate reductase [47, 48]. Moreover, genes encoding for membrane transporter for DMSP and glycine betaine are found in the genome of four strains of Prochlorococcus, all of them members of the lowlight clade of this cyanobacteria (Fig. 1, Supplementary Table $1[21,49])$.

\section{ATP and phosphonates}

The importance of the metabolization of dissolved organic phosphorus has been increasingly highlighted for the last years [50-57]. Moreover, light-stimulated uptake of 
Table 1 Specific uptake rates of organic compounds by Prochlorococcus and Synechococcus determined under selected experimental conditions, in the field and in the laboratory.

\begin{tabular}{|c|c|c|c|c|}
\hline & \multicolumn{2}{|l|}{ Prochlorococcus } & \multicolumn{2}{|l|}{ Synechococcus } \\
\hline & Field & Laboratory & Field & Laboratory \\
\hline Amino acid & $\begin{array}{l}1.442 \pm 0.814 \\
\left(\mathrm{amol} / \text { cell day }^{\mathrm{a}}\right.\end{array}$ & $\begin{array}{l}2.88 \pm 0.24 \\
\left(\mathrm{amol} / \mathrm{cell}^{\mathrm{day}}\right)^{\mathrm{b}}\end{array}$ & $\begin{array}{l}1.258 \pm 0.538 \\
\left(\mathrm{amol} / \text { cell day }^{\mathrm{a}}\right.\end{array}$ & \\
\hline DMSP & $\begin{array}{l}0.0596 \\
(\text { amol/cell day })^{\mathrm{c}}\end{array}$ & & $\begin{array}{l}0.21 \\
(\text { amol/cell day })^{\mathrm{c}}\end{array}$ & \\
\hline ATP & $\begin{array}{l}0.672 \\
(\mathrm{amol} / \mathrm{cell} \text { day })^{\mathrm{d}}\end{array}$ & $\begin{array}{l}480 \\
(\text { amol/cell day })^{\mathrm{e}}\end{array}$ & $\begin{array}{l}0.672 \\
\left(\mathrm{amol} / \text { cell day }^{\mathrm{d}}{ }^{\mathrm{a}}\right.\end{array}$ & \\
\hline Glucose & 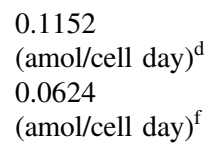 & $\begin{array}{l}256.23 \pm 29.45 \\
(\text { amol/cell day })^{\mathrm{g}} \\
16.15 \pm 1.37 \\
(\mathrm{pmol} / \mathrm{min} \mathrm{mg} \text { prot })^{\mathrm{h}}\end{array}$ & $\begin{array}{l}0.144 \\
\left(\mathrm{amol} / \text { cell day }^{\mathrm{d}}\right.\end{array}$ & $\begin{array}{l}1.21 \pm 0.18 \\
(\mathrm{pmol} / \mathrm{min} \mathrm{mg} \operatorname{prot})^{\mathrm{h}}\end{array}$ \\
\hline \multicolumn{5}{|c|}{${ }^{\mathrm{a}}$ Determination provided by the authors [82]. } \\
\hline \multicolumn{5}{|c|}{${ }^{\mathrm{b}}$ Calculated on the basis of the reported data [81]. } \\
\hline \multicolumn{5}{|c|}{${ }^{\mathrm{c}}$ Determination provided by the authors [32]. } \\
\hline \multicolumn{5}{|c|}{${ }^{\mathrm{d}}$ Calculated on the basis of the reported data. Determined in the Pacific Ocean [27]. } \\
\hline \multicolumn{5}{|c|}{ e In P-limited cultures; calculated on the basis of the reported data [88]. } \\
\hline \multicolumn{5}{|c|}{${ }^{\mathrm{f}}$ Determined in the Atlantic Ocean [64]. } \\
\hline \multicolumn{5}{|c|}{${ }^{\mathrm{g}}[63]}$. \\
\hline
\end{tabular}

phosphorus-containing compounds might offer a competitive advantage of phototrophic microorganisms over chemotrophic ones, although phytoplankton are able to sustain a relatively high phosphorus transport in the dark, which must be beneficial since the uptake of this compounds into the cell is an energy-costly process [52].

Dissolved organic phosphorus compounds in oligotrophic oceanic areas include phosphate esters as the largest class of phosphorus-containing compounds, followed by phosphonates [58]. Both SAR11 alphaproteobacterial clade and the Prochlorococcus genera have shown light-stimulated uptake of ATP [38, 50, 52]. However, other bacterioplankton did not demonstrate this light-stimulated response [38].

Phosphonates are reduced organophosphorus compounds with a highly stable carbon-phosphorus bond, which can be found at relatively high concentrations in the oceans [58]. Phosphorus availability appears as a major selective pressure that has shaped the genome content and adaptations shown by abundant bacterial populations [59]. Therefore, the presence of pathways for the transport and hydrolysis of bioavailable organic phosphorus sources in seawater (phosphonates and phosphate esters) are in agreement with their decisive role in bacteria to cope with inorganic phosphorus scarcity in the ocean $[55,56,60]$.

\section{Sugars}

Although initial studies on Prochlorococcus PCC 9511 strain showed no indication for sugar employment as energy source
[61], psbA expression decreased upon glucose addition in cultures subjected to darkness [62], suggesting that Prochlorococcus could use glucose as an alternative energy source under light limitation. Later, glucose uptake has been demonstrated in Prochlorococcus and Synechococcus strains using both laboratory cultures and natural populations [14, 54, 63, 64]. Furthermore, higher abundance of Prochlorococcus upon addition of glucose and mannitol was observed in oligotrophic areas of South Pacific [65].

Experiments performed in laboratory cultures revealed a substantial diversity in the rate of glucose uptake within Prochlorococcus strains [63]. Glucose transport in Prochlorococcus and Synechococcus displays multiphasic kinetic with high affinity $K s$ matching the glucose concentration estimated for the oligotrophic Atlantic Ocean, in the nanomolar range (Fig. 2) [14, 64]. However, comparison of uptake efficiency (calculated by dividing the uptake rate by the $\mathrm{K}_{s}$ constant [64]) demonstrated Prochlorococcus to be 7 times more efficient than Synechococcus despite of the $\mathrm{K}_{s}$ value to be 6 times lower than that described for Prochlorococcus [14]. The glucose uptake rates observed in the field are very low (Table 1), Prochlorococcus contributing to ca. $5 \%$ of the total microbial glucose uptake $[54,64]$ and there is the caveat that uptake determinations are close to detection limits. This notwithstanding, glucose uptake has been observed in the laboratory [14, 63] and in the field at different locations [54, 64], by different teams. More precise uptake determination methods will allow to assess in the future the actual contribution of glucose to $\mathrm{C}$ metabolism in picocyanobacterial populations in the ocean. 


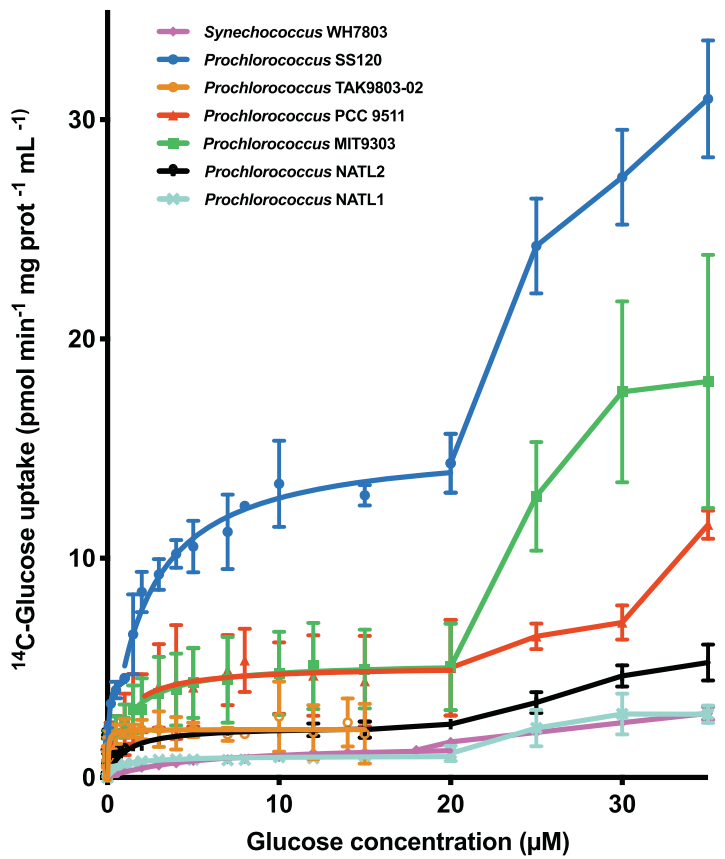

Fig. 2 Glucose uptake kinetics in Prochlorococcus sp. strains SS120, TAK9803-2, PCC 9511, MIT9303, NATL2, and NATL1 and Synechococcus sp. strain WH7803. The chart shows ${ }^{14} \mathrm{C}$-glucose concentration versus its uptake. Data are replotted from [64] and [14].

Genome analysis of Prochlorococcus strains nominated a gene annotated as $\mathrm{melB}$ (melibiose transporter, later nominated $g l(\mathrm{cH}$ ), as a putative candidate for glucose transporter [63]. The ectopic expression of this gene demonstrated that the protein encoded by $\mathrm{glcH}$ confers the capacity of glucose uptake to Synechococcus sp. strain PCC 7942, a strain naturally unable to transport glucose. Furthermore, transport in this mutant replicates the same multiphasic kinetics shown by Prochlorococcus cells. Sugar competition experiments, performed in this mutant, where other sugar was added together with glucose, allowed to establish that GlcH is highly specific for glucose [64]. Characterization by inhibitors suggests glucose transport to be dependent on ATP production and therefore to be active [14].

Several studies have dealt with the effect of glucose availability on transport rate, gene expression, and protein abundances. The gene encoding the high affinity transporter, $g l c H$, is expressed in the absence of added glucose and increases, upon glucose addition, in Prochlorococcus and Synechococcus [63, 66]. The diversity of the response of glcH expression to the availability of glucose or to darkness is remarkable, reflecting the different habitats where the strains proliferate: higher response is shown for low-light adapted strains as SS120 [66].

Two pathways have been designated in cyanobacteria for glucose assimilation [14, 63, 67]: the pentose phosphate and the Entner-Doudoroff pathways. Relative quantification of gene expression suggested pentose phosphate to be involved in glucose metabolization in Prochlorococcus, since the expression of the genes $z w f$ (encoding for glucose 6P dehydrogenase), gnd (encoding for glucose 6P gluconate dehydrogenase), and tal (encoding for transaldolase) increased upon glucose addition [14, 63]. Quantitative proteomics also revealed increases in protein abundance of enzymes related to pentose phosphate and Entner-Doudoroff pathways [14] although these changes were not dramatic. These studies do not allow to clarify which is the primary pathway allowing metabolization of glucose in Prochlorococcus.

It was early demonstrated that glucose uptake is essentially detained in cyanobacteria, both in the dark and by the addition of DCMU (3-(3,4-dichlorophenyl)-1,1-dimethylurea), an inhibitor of photosystem II [68]. Preincubation in the dark for $24 \mathrm{~h}$ promotes a decrease in glucose uptake of ca. 40\% in Prochlorococcus sp. strain SS120 [63]. Furthermore, addition of DCMU and DBMIB (2,5-dibromo-6isopropyl-3-methyl-1,4-benzoquinone, another inhibitor of the photosynthetic electron transport) also decreases glucose uptake using the same strain [14]. In addition, DCMU reduces glucose uptake in natural picocyanobacterial populations [54]. All these results suggest that light availability is an important factor affecting glucose utilization. Darkness promotes a decrease in the expression of $\mathrm{glcH}$ with a high diversity of responses depending on the Prochlorococcus and Synechococcus strain [66]. These results may suggest a higher regulatory capacity of glucose uptake in low-light adapted cyanobacterial strains.

\section{Genomic and metagenomic analysis of mixotrophic metabolism in marine picocyanobacteria}

First metagenomic analysis in the photic zone, which found mixotrophy lifestyle, showed the presence of genes associated with the uptake of amino acids and amino sugars in microbial communities including Prochlorococcus [69]. In contrast, deep water samples (from depths of $200 \mathrm{~m}$ and below) were not enriched in this kind of genes. Later, genes involved in amino acids, sugars, and peptides uptake and also in the degradation pathways of these compounds were identified in 67 strains of the genera Prochlorococcus and Synechococcus [70]. The authors examined the Tara Oceans marine metagenomic survey [71, 72], finding a universal mixotrophy capacity for marine picocyanobacteria (Fig. 1), which was more dominant in deeper waters [70]. This is consistent with the higher concentrations of nutrients in these waters [73].

All Prochlorococcus clades possess the high affinity glucose transporter $\mathrm{glcH}$ gene, suggesting that this gene is important for Prochlorococcus and it has been subjected to selective evolution [14]. This importance is reinforced by the widespread distribution of $g l c H$ in the ocean [70] and the large 
diversity in glucose uptake kinetics within Prochlorococcus strains [14]. This transporter was consistently found in all picocyanobacterial reference genomes in a gene cluster with a glycogen debranching enzyme (E.C. 3.2.1.-), which suggests both genes function would be providing glucose to the cell.

All Prochlorococcus clades have a single glucose transporter gene $(g l c H)$, except clade LL IV where the presence of $g l c P$, a specific glucose permease found in freeliving and symbiotic cyanobacteria [74], has also been reported and normally located proximate to the sugar porin oprB [70]. By contrast, some Synechococcus also possess more than one gene coding for sugar transporters [70].

Pangenomic analysis identified multiple sugar metabolism genes in Prochlorococcus strains that were absent in previously published metagenomic analyses [75]. Methodological differences could explain the low detection of some genes by metagenomic analysis since pangenomic gene clusters are formed based on homology between amino acid sequences, while metagenomic analyses are done at the DNA sequence level [75]. Using pangenomic analysis, these authors revealed a small set of core genes linked to sugar metabolism that mostly occurred in hypervariable genomic island of the Prochlorococcus populations suggesting potential benefits to Prochlorococcus populations [75].

\section{Potential role for vesicles in mixotrophy}

Many bacterial species release extracellular vesicles, which have roles in various processes, including quorum sensing, virulence, and horizontal gene transfer [76]. Bacterial vesicles have been observed in marine ecosystems, produced by Prochlorococcus and Synechococcus [77]. In coastal and open water seawater samples, these vesicles range from 70 to $100 \mathrm{~nm}$ in size and contain lipids, proteins, and nucleic acids from different bacteria taxes, not only Prochlorococcus or Synechococcus [77].

Based on the number of vesicles found in Prochlorococcus cultures, it is estimated that wild Prochlorococcus cells release $10^{27}-10^{28}$ vesicles [77] into the oceans every day, a very significant amount of organic compounds, suggesting important implications for carbon cycling in marine systems [77, 78].

For marine cyanobacteria living in oligotrophic areas, the secretion of vesicles may seem a waste of resources. However, potential beneficial functions have been suggested for these vesicles, such as promoting the growth of "helper" bacteria, reducing viral attacks or even as gene transfer vehicles [77-79]. The hypothesis that Prochlorococcus and Synechococcus vesicles can be used for nutrient transfer suggests an important impact on the marine carbon flux.

Furthermore, the presence of proteins and nucleic acids within vesicles would imply a potential role as $\mathrm{N}$ and $\mathrm{P}$ sources as well. The fact that other bacteria appear to depend on theses vesicles content (for lost metabolic functions or nutrients as organic carbon) to persist in their environments is consistent with the coevolutionary dynamics expected under the Black Queen hypothesis [80].

\section{Ecological relevance}

Utilization of organic compounds by marine picocyanobacteria forces to reconsider their role in the oceanic metabolic fluxes. But the question is: where does the value of these molecules come from? Why does the assimilation of organic molecules represent a worthy investment? Possible answers to this question will be explored in this section.

\section{Provision of limiting elements in oligotrophic environments}

The first studies showing organic molecules uptake by marine picocyanobacteria were focused on amino acids $[28,30,33-35,39,81,82]$ and later, DMSP [32, 45, 46] and ATP [52, 54] uptake was also demonstrated. These molecules contained chemical elements, as $\mathrm{N}$ or $\mathrm{P}$, which are found at low concentrations in the oligotrophic environments where Prochlorococcus and some Synechococcus clades are most abundant. Therefore, the uptake of those elements containing molecules was initially considered as a way of obtaining essential resources. Furthermore, early studies proposed that a high efficiency in amino acids uptake might be one of the reasons underlying the dominance of Prochlorococcus in the oceans [33].

\section{Energy savings}

The cost of glucose uptake by marine picocyanobacteria has not been calculated on the basis of experimental data, but it is carried out by a transporter similar to the $m e l B$-encoded melibiose-sodium symporter [83]. If we assume a similar molecular mechanism for both homologous transporters, it would mean that the uptake of three glucose molecules consumes 1 ATP when taken up from the environment; by contrast, biosynthesis of one glucose molecule consumes the equivalent of 18 ATP [64]. This simple comparison shows that when organic compounds are available in the environment, it makes ecological sense to take them up, regardless of whether they contain limiting elements or not.

\section{Removal of resources that might be used by competitors}

A third hypothesis to be considered is that picocyanobacteria take up organic compounds as a way to deplete 
resources, which might be used by coexisting competitors (be it mixotrophic or heterotrophic) [84]. This strategy would be especially useful in oligotrophic habitats, allowing picocyanobacteria to become dominant players in these areas. If this hypothesis holds true, then the advantage offered by mixotrophy to marine picocyanobacteria would come from displacing potential competitors.

\section{Coevolved mutualism}

This hypothesis proposes that Prochlorococcus metabolic rate (and also its organic carbon excretion rate) have increased over the course of the evolution [9]. As a consequence, there is a depletion of nutrients in the ocean surface, resulting in an increase in total biomass at the ecosystem level, and promoting the coevolution of cells in that ecosystem. Furthermore, this model proposes that the metabolic codependencies of Prochlorococcus and SAR11 are similar to those of chloroplasts and mitochondria in vegetal cells, by interchanging glycolate or pyruvate (from Prochlorococcus to SAR11) and malate (from SAR11 to Prochlorococcus). Addition of glucose and pyruvate (but not of glucose alone) has also been shown to extend the survival of Prochlorococcus under darkness [85], highlighting the role of external organic compounds on the physiology of marine picocyanobacteria.

Coevolved mutualism is in sharp contrast with previous ideas regarding the adaptive strategies of Prochlorococcus to oligotrophic environments, including small cell size, a small, streamlined genome, and a high surface/volume ratio. This involved that nutrients were scavenged by Prochlorococcus, but rarely released to the environment. The discovery of vesicles produced by Prochlorococcus and Synechococcus was shocking in this regard [77, 86], since it contradicted those previous ideas: the vesicles released contained a wide range of organic compounds. Release of organic carbon might be related to making iron bioavailable, and this would indirectly push the oceans from an anoxic, iron-free rich state to an oxygenated state with organic carbon molecules binding iron [5].

\section{Conclusion}

The discovery of organic compounds utilization by Prochlorococcus and Synechococcus has profound implications for the understanding of marine microbial ecology. The substrate specificity, kinetics, and regulation of most transporters annotated in marine picocyanobacterial genomes remain an open question, requiring molecular analysis for confirmation; in this regard, the development of a genetic system in Prochlorococcus [87] will be an invaluable tool. The pathways for assimilation of the different compounds, and their relative contribution to the nutrition of the cells, should also be analyzed in detail to understand the impact of mixotrophy on the growth of marine cyanobacterial populations. Further quantitative studies in the field determining the uptake rates for different compounds at different oceanic regions are needed to assess the consequences of marine cyanobacterial mixotrophy for global biogeochemical cycles. This, in turn, will help us to understand how global warming might affect the nutritional balance of these populations in the future.

Acknowledgements Work of the authors on mixotrophy in marine picocyanobacteria has been funded by Gobierno de España (grants BFU2009/08008/BMC, BFU2013-44767-P, and BFU2016-76227-P, Ministerio de Ciencia, Innovación y Universidades, cofunded by European Regional Development Fund), Junta de Andalucía (Excellence projects P07-CVI-3055 and P12-BIO-2141, Consejería de Conocimiento, Investigación y Universidad, cofunded by European Regional Development Fund), and Universidad de Córdoba (Programa Propio de Investigación). We are indebted to Dr. Pedro Candau (Instituto de Bioquímica Vegetal y Fotosíntesis, Sevilla, Spain), Dr. Ignacio Luque (Instituto de Bioquímica Vegetal y Fotosíntesis, Sevilla, Spain) and Prof. Mikhail Zubkov (Scottish Association for Marine Science, United Kingdom) and their teams, since their collaboration was essential in our studies on glucose uptake in marine picocyanobacteria. We thank Prof. Josep M. Gasol and his team (Institut de Ciències del Mar-CMIMA, CSIC, Barcelona, Spain) and Prof. Mikhail Zubkov (Scottish Association for Marine Science, United Kingdom) for providing DMSP and amino acid uptake rates by Prochlorococcus and Synechococcus in the field, respectively.

\section{Compliance with ethical standards}

Conflict of interest The authors declare that they have no conflict of interest.

Publisher's note Springer Nature remains neutral with regard to jurisdictional claims in published maps and institutional affiliations.

\section{References}

1. Bekker A, Holland HD, Wang PL, Rumble D, Stein HJ, Hannah JL, et al. Dating the rise of atmospheric oxygen. Nature. 2004; 427:117-20.

2. Chisholm SW, Olson RJ, Zettler ER, Goericke R, Waterbury JB, Welschmeyer NA. A novel free living prochlorophyte abundant in the oceanic euphotic zone. Nature. 1988;334:340-3.

3. Waterbury J, Watson S, Guillard R, Brand L. Widespread occurrence of a unicellular, marine planktonic, cyanobacterium. Nature. 1979;277:293-4.

4. Flombaum P, Gallegos JL, Gordillo RA, Rincón J, Zabala LL, Jiao N, et al. Present and future global distributions of the marine cyanobacteria Prochlorococcus and Synechococcus. Proc Natl Acad Sci USA. 2013;110:9824-9.

5. Braakman R. The emergence of a globally productive biosphere. Free Radic Biol Med. 2019;140:172-87.

6. Partensky F, Hess W, Vaulot D. Prochlorococcus, a marine photosynthetic prokaryote of global significance. Microbiol Mol Biol Rev. 1999;63:106-27.

7. Biller SJ, Berube PM, Lindell D, Chisholm SW. Prochlorococcus: the structure and function of collective diversity. Nat Rev Microbiol. 2015;13:13-27. 
8. Scanlan DJ, Ostrowski M, Mazard S, Dufresne A, Garczarek L, Hess WR, et al. Ecological genomics of marine picocyanobacteria. Microbiol Mol Biol Rev. 2009;73:249-99.

9. Braakman R, Follows MJ, Chisholm SW. Metabolic evolution and the self-organization of ecosystems. Proc Natl Acad Sci USA. 2017;114:E3091-100.

10. Berube PM, Biller SJ, Hackl T, Hogle SL, Satinsky BM, Becker JW, et al. Single cell genomes of Prochlorococcus, Synechococcus, and sympatric microbes from diverse marine environments. Sci Data. 2018;5:180154.

11. Zubkov MV, Hartmann M. Ecological significance of microbial trophic mixing in the oligotrophic ocean: the Atlantic Ocean case studies. In: Gasol JM, Kirchman DL, editors. Microbial ecology of the oceans, 3rd ed. Hoboken: Wiley Blackwell; 2018.

12. Stoecker DK, Hansen PJ, Caron DA, Mitra A. Mixotrophy in the marine plankton. Annu Rev Mar Sci. 2017;9:311-35.

13. Cottrell MT, Kirchman DL. Photoheterotrophic microbes in the Arctic Ocean in summer and winter. Appl Environ Microbiol. 2009;75:4958-66.

14. Muñoz-Marín MC, Gómez-Baena G, Diez J, Beynon RJ, González-Ballester D, Zubkov MV, et al. Glucose uptake in Prochlorococcus: diversity of kinetics and effects on the metabolism. Front Microbiol. 2017;8:327.

15. Rippka R. Photoheterotrophy and chemoheterotrophy among unicellular blue-green algae. Arch Microbiol. 1972;87:93-8.

16. Hoare D, Hoare S, Moore R. The photoassimilation of organic compounds by autotrophic blue-green algae. J Gen Microbiol. 1967;49:351-70.

17. Rippka R, Deruelles J, Waterbury JB, Herdman M, Stanier RY. Generic assignments, strain histories and properties of pure cultures of cyanobacteria. J Gen Microbiol. 1979;111:1-6.

18. Karl DM. Microbial oceanography: paradigms, processes and promise. Nat Rev Microbiol. 2007;5:759-69.

19. Dufresne A, Salanoubat M, Partensky F, Artiguenave F, Axmann I, Barbe V, et al. Genome sequence of the cyanobacterium Prochlorococcus marinus SS120, a nearly minimal oxyphototrophic genome. Proc Natl Acad Sci USA. 2003;100:10020-5.

20. Palenik B, Brahamsha B, Larimer F, Land M, Hauser L, Chain P, et al. The genome of a motile marine Synechococcus. Nature. 2003; 424:1037-42.

21. Rocap G, Larimer F, Lamerdin J, Malfatti S, Chain P, Ahlgren N, et al. Genome divergence in two Prochlorococcus ecotypes reflects oceanic niche differentiation. Nature. 2003;424:1042-7.

22. Eiler A. Evidence for the ubiquity of mixotrophic bacteria in the upper ocean: implications and consequences. Appl Environ Microbiol. 2006;72:7431-7.

23. Tittel J, Bissinger V, Zippel B, Gaedke U, Bell E, Lorke A, et al. Mixotrophs combine resource use to outcompete specialists: implications for aquatic food webs. Proc Natl Acad Sci USA. 2003;100:12776-81.

24. Vage S, Castellani M, Giske J, Thingstad TF. Successful strategies in size structured mixotrophic food webs. Aquat Ecol. 2013;47:329-47.

25. Hartmann M, Grob C, Tarran GA, Martin AP, Burkill PH, Scanlan DJ, et al. Mixotrophic basis of Atlantic oligotrophic ecosystems. Proc Natl Acad Sci USA. 2012;109:5756-60.

26. Giovannoni S, Tripp H, Givan S, Podar M, Vergin K, Baptista D, et al. Genome streamlining in a cosmopolitan oceanic bacterium. Science. 2005;309:1242-5.

27. Zubkov MV. Photoheterotrophy in marine prokaryotes. J Plankton Res. 2009;31:933-8.

28. Church M, Ducklow H, Karl DM. Light dependence of $\left[{ }^{3} \mathrm{H}\right]-$ Leucine incorporation in the oligotrophic North Pacific Ocean. Appl Environ Microbiol. 2004;70:4079-87.

29. Church M, Ducklow H, Letelier R, Karl DM. Temporal and vertical dynamics in picoplankton photoheterotrophic production in the subtropical North Pacific Ocean. Aquat Micro Ecol. 2006; 45:41-53.

30. Michelou V, Cottrell M, Kirchman D. Light-stimulated bacterial production and amino acid assimilation by cyanobacteria and other microbes in the North Atlantic Ocean. Appl Environ Microbiol. 2007;73:5539-46.

31. Paerl H. Ecophysiological and trophic implications of lightstimulated amino acid utilization in marine picoplankton. Appl Environ Microbiol. 1991;57:473-9.

32. Ruiz-González C, Simó R, Vila-Costa M, Sommaruga R, Gasol J. Sunlight modulates the relative importance of heterotrophic bacteria and picophytoplankton in DMSP-sulphur uptake. ISME J. 2012;6:650-9.

33. Zubkov M, Fuchs B, Tarran G, Burkill P, Amann R. High rate of uptake of organic nitrogen compounds by Prochlorococcus cyanobacteria as a key to their dominance in oligotrophic oceanic waters. Appl Environ Microbiol. 2003;69:1299-304.

34. Zubkov M, Tarran G, Fuchs B. Depth related amino acid uptake by Prochlorococcus cyanobacteria in the Southern Atlantic tropical gyre. FEMS Microbiol Ecol. 2004;50:153-61.

35. Zubkov M, Tarran G. Amino acid uptake of Prochlorococcus spp. in surface waters across the South Atlantic Subtropical Front. Aquat Micro Ecol. 2005;40:241-9.

36. Aldunate M, Henriquez-Castillo C, Ji QX, Lueders-Dumont J, Mulholland MR, Ward BB, et al. Nitrogen assimilation in picocyanobacteria inhabiting the oxygen-deficient waters of the eastern tropical North and South Pacific. Limnol Oceanogr. 2019.

37. Duhamel S, Moutin T. Carbon and phosphate incorporation rates of microbial assemblages in contrasting environments in the Southeast Pacific. Mar Ecol Prog Ser. 2009;375:53-64.

38. Gómez-Pereira PR, Hartmann M, Grob C, Tarran GA, Martin AP, Fuchs BM, et al. Comparable light stimulation of organic nutrient uptake by SAR11 and Prochlorococcus in the North Atlantic subtropical gyre. ISME J. 2013;7:603-14.

39. Mary I, Tarran G, Warwick P, Terry M, Scanlan D, Burkill P, et al. Light enhanced amino acid uptake by dominant bacterioplankton groups in surface waters of the Atlantic Ocean. FEMS Microbiol Ecol. 2008;63:36-45.

40. Björkman KM, Church MJ, Doggett JK, Karl DM. Differential assimilation of inorganic carbon and leucine by Prochlorococcus in the oligotrophic North Pacific subtropical gyre. Front Microbiol. 2015;6:1401.

41. Kiene R, Linn LJ, Bruton JA. New and important roles for DMSP in marine microbial communities. J Sea Res. 2000;43:209-24.

42. Moran MA, Durham BP. Sulfur metabolites in the pelagic ocean. Nat Rev Microbiol. 2019;17:665-78.

43. Kiene RP. Dimethyl sulfide production from dimethylsulfoniopropionate in coastal seawater samples and bacterial cultures. Appl Environ Microbiol. 1990;56:3292-7.

44. Sunda W, Kieber DJ, Kiene RP, Huntsman S. An antioxidant function for DMSP and DMS in marine algae. Nature. 2002; 418:317-20.

45. Malmstrom RR, Kiene R, Vila M, Kirchman KL. Dimethylsulfoniopropionate (DMSP) assimilation by Synechococcus in the Gulf of Mexico and northwest Atlantic Ocean. Limnol Oceanogr. 2005;50:1924-31.

46. Vila-Costa M, Simo R, Harada H, Gasol J, Slezak D, Kiene R. Dimethylsulfoniopropionate uptake by marine phytoplankton. Science. 2006;314:652-4.

47. López-Lozano A, Diez J, El Alaoui S, Moreno-Vivián C, GarcíaFernández J. Nitrate is reduced by heterotrophic bacteria but not transferred to Prochlorococcus in non axenic cultures. FEMS Microbiol Ecol. 2002;41:151-60.

48. Moore L, Post A, Rocap G, Chisholm S. Utilization of different nitrogen sources by the marine cyanobacteria Prochlorococcus and Synechococcus. Limnol Oceanogr. 2002;47:989-96. 
49. Becker JW, Hogle SL, Rosendo K, Chisholm SW. Co-culture and biogeography of Prochlorococcus and SAR11. ISME J. 2019;13: 1506-19.

50. Casey JR, Lomas MW, Michelou VK, Dyhrman ST, Orchard ED, Ammerman JW, et al. Phytoplankton taxon-specific orthophosphate $(\mathrm{Pi})$ and ATP utilization in the western subtropical North Atlantic. Aquat Micro Ecol. 2009;58:31-44.

51. Duhamel S, Bjorkman KM, Van Wambeke F, Moutin T, Karl DM. Characterization of alkaline phosphatase activity in the North and South Pacific Subtropical Gyres: Implications for phosphorus cycling. Limnol Oceanogr. 2011;56:1244-54.

52. Duhamel S, Björkman K, Karl DM. Light dependence of phosphorus uptake by microorganisms in the subtropical North and South Pacific Ocean. Aquat Micro Ecol. 2012;67:225-38.

53. Duhamel S, Bjorkman KM, Doggett JK, Karl DM. Microbial response to enhanced phosphorus cycling in the North Pacific Subtropical Gyre. Mar Ecol Prog Ser. 2014;504:43-58.

54. Duhamel S, Van Wambeke F, Lefevre D, Benavides M, Bonnet S. Mixotrophic metabolism by natural communities of unicellular cyanobacteria in the western tropical South Pacific Ocean. Environ Microbiol. 2018;20:2743-56.

55. Orchard ED, Ammerman JW, Lomas MW, Dyhrman ST. Dissolved inorganic and organic phosphorus uptake in Trichodesmium and the microbial community: the importance of phosphorus ester in the Sargasso Sea. Limnol Oceanogr. 2010;55:1390-9.

56. Sosa OA, Casey JR, Karl DM. Methylphosphonate oxidation in Prochlorococcus strain MIT9301 supports phosphate acquisition, formate excretion, and carbon assimilation into purines. Appl Environ Microbiol. 2019;85:e00289-19.

57. Sosa OA, Repeta DJ, DeLong EF, Ashkezari MD, Karl DM. Phosphate-limited ocean regions select for bacterial populations enriched in the carbon-phosphorus lyase pathway for phosphonate degradation. Environ Microbiol. 2019;21:2402-14.

58. Young CL, Ingall ED. Marine dissolved organic phosphorus composition: insights from samples recovered using combined electrodialysis/reverse osmosis. Aquat Geochem. 2010;16:563-74.

59. Coleman ML, Chisholm SW. Ecosystem-specific selection pressures revealed through comparative population genomics. Proc Natl Acad Sci USA. 2010;107:18634-9.

60. Dyhrman ST, Ammerman JW, Van Mooy BAS. Microbes and the marine phosphorus cycle. Oceanography. 2007;20:110-6.

61. Rippka R, Coursin T, Hess W, Lichtlé C, Scanlan D, Palinska K, et al. Prochlorococcus marinus Chisholm et al. 1992 subsp. pastoris subsp. nov. strain PCC 9511, the first axenic chlorophyll $a_{2} / b_{2}$-containing cyanobacterium (Oxyphotobacteria). Int J Syst Evol Microbiol. 2000;50:1833-47.

62. García-Fernández JM, Hess WR, Houmard J, Partensky F. Expression of the $p s b A$ gene in the marine oxyphotobacteria Prochlorococcus spp. Arch Biochem Biophys. 1998;359:17-23.

63. Gómez-Baena G, López-Lozano A, Gil-Martínez J, Lucena J, Diez J, Candau P, et al. Glucose uptake and its effect on gene expression in Prochlorococcus. PLoS ONE. 2008;3:e3416.

64. Muñoz-Marín MC, Luque I, Zubkov MV, Hill PG, Diez J, GarcíaFernández JM. Prochlorococcus can use the Pro1404 transporter to take up glucose at nanomolar concentrations in the Atlantic Ocean. Proc Natl Acad Sci USA. 2013;110:8597-602.

65. Moisander PH, Zhang R, Boyle EA, Hewson I, Montoya JP, Zehr JP. Analogous nutrient limitations in unicellular diazotrophs and Prochlorococcus in the South Pacific Ocean. ISME J. 2012;6:733-44.

66. Moreno-Cabezuelo JA, López-Lozano A, Díez J, GarcíaFernández JM. Differential expression of the glucose transporter gene $\mathrm{glcH}$ in response to glucose and light in marine picocyanobacteria. PeerJ. 2019;6:e6248.
67. Chen X, Schreiber K, Appel J, Makowka A, Fahnrich B, Roettger $\mathrm{M}$, et al. The Entner-Doudoroff pathway is an overlooked glycolytic route in cyanobacteria and plants. Proc Natl Acad Sci USA. 2016;113:5441-6.

68. Pelroy R, Rippka R, Stanier R. Metabolism of glucose by unicellular blue-green algae. Arch Microbiol. 1972;87:303-22.

69. DeLong EF, Preston CM, Mincer T, Rich V, Hallam SJ, Frigaard $\mathrm{NU}$, et al. Community genomics among stratified microbial assemblages in the ocean's interior. Science. 2006;311:496-503.

70. Yelton AP, Acinas SG, Sunagawa S, Bork P, Pedros-Alio C, Chisholm SW. Global genetic capacity for mixotrophy in marine picocyanobacteria. ISME J. 2016;10:2946-57.

71. Karsenti E, Acinas SG, Bork P, Bowler C, De Vargas C, Raes J, et al. A holistic approach to marine eco-systems biology. PLOS Biol. 2011;9:e1001177.

72. Sunagawa S, Coelho LP, Chaffron S, Kultima JR, Labadie K, Salazar G. et al. Structure and function of the global ocean microbiome. Science. 2015;348:1261359-1261351.

73. Cullen J. Subsurface chlorophyll maximum layers: enduring enigma or mystery solved? Annu Rev Mar Sci. 2015;7:207-39.

74. Picossi S, Flores E, Ekman M. Diverse roles of the GlcP glucose permease in free-living and symbiotic cyanobacteria. Plant Signal Behav. 2013;8:e27416.

75. Delmont TO, Eren AM. Linking pangenomes and metagenomes: the Prochlorococcus metapangenome. PeerJ. 2018;6:e4320.

76. Toyofuku M, Nomura N, Eberl L. Types and origins of bacterial membrane vesicles. Nat Rev Microbiol. 2019;17:13-24.

77. Biller SJ, Schubotz F, Roggensack SE, Thompson AW, Summons RE, Chisholm SW. Bacterial vesicles in marine ecosystems. Science. 2014;343:183-6.

78. Scanlan D. Bacterial vesicles in the ocean. Science. 2014;343: $143-4$.

79. Soler N, Krupovic M, Marguet E, Forterre P. Membrane vesicles in natural environments: a major challenge in viral ecology. ISME J. 2015;9:793-6.

80. Morris JJ, Lenski RE, Zinser ER. The Black Queen hypothesis: evolution of dependencies through adaptive gene loss. mBio. 2012;3:e0036-12.

81. Mary I, Garczarek L, Tarran G, Kolowrat C, Terry M, Scanlan D, et al. Diel rhythmicity in amino acid uptake by Prochlorococcus. Environ Microbiol. 2008;10:2124-31.

82. Zubkov M, Tarran G, Mary I, Fuchs B. Differential microbial uptake of dissolved amino acids and amino sugars in surface waters of the Atlantic Ocean. J Plankton Res. 2008;30:211-20.

83. Ethayathulla AS, Yousef MS, Amin A, Leblanc G, Kaback HR, Guan L. Structure-based mechanism for $\mathrm{Na}(+) /$ melibiose symport by MelB. Nat Commun. 2014;5:3009.

84. Ghoul M, Mitri S. The ecology and evolution of microbial competition. Trends Microbiol. 2016;24:833-45.

85. Coe A, Ghizzoni J, LeGault K, Biller S, Roggensack SE, Chisholm SW. Survival of Prochlorococcus in extended darkness. Limnol Oceanogr. 2016;71:1375-88.

86. Biller SJ, McDaniel LD, Breitbart M, Rogers E, Paul JH, Chisholm SW. Membrane vesicles in sea water: heterogeneous DNA content and implications for viral abundance estimates. ISME J. 2017;11:394-404.

87. Laurenceau R, Bliem C, Osburne MS, Becker JW, Biller SJ, Cubillos-Ruiz A, et al. Toward a genetic system in the marine cyanobacterium Prochlorococcus. 2019. https://doi.org/10.1101/820027.

88. Krumhardt KM, Callnan K, Roache-Johnson K, Swett T, Robinson D, Reistetter EN, et al. Effects of phosphorus starvation versus limitation on the marine cyanobacterium Prochlorococcus MED4 I: uptake physiology. Environ Microbiol. 2013;20:2114-28. 